\title{
Technology, Productivity and Employment: An Empirical Analysis of Indian Industries
}

Suresh Chand Aggarwal

Former Professor and Dean, Department of Business Economics, University of Delhi, South Campus, New Delhi-110021, India; sureshchag@yahoo.com

\begin{abstract}
Since 2000, technology has changed at a tremendous pace and has transformed the face of industry in the entire world. Many among the top Fortune 500 companies, Amazon, Apple, Facebook, Google, Microsoft, Uber, Wal-Mart, are all technology driven and are also mainly in the services sector. While opening many new windows for investment and increase in productivity, the new technology is simultaneously disturbing the existing technological complementarities and exerting a lot of pressure on the supply of the matching skill. Many jobs which exist today would disappear tomorrow and many new jobs will get created tomorrow which do not exist today. So there is a simultaneous creation and destruction of jobs and the net impact thus depends upon their respective pace. Skill mismatches are now a common feature in all economies. While new technology is expected to increase productivity of labour and hence employment especially- in the long run, it is also simultaneously expected to displace some labour because of its very nature in the short run. A part of the explanation for the structural shift in employment in India from agriculture to services could lie in the availability and use of new technology. The present paper aims to look at the impact of technology change on labour productivity growth and employment growth for the Indian manufacturing and service industry.
\end{abstract}

Keywords: Employment, Growth, Productivity, Skills, Technology

JEL classification: J24

\section{Introduction}

The new technology in last around one and a half decade- Internet of Things (IOT); Artificial Intelligence (AI); machine learning; neural networks; digitization of manufacturing; etc. has changed and is changing the face of how we work, and the skills we need to succeed in our jobs. Skills development has become central to economic performance of the countries in the current milieu when 'disruptive' technology is evolving at a fast pace. But the speed at which jobs are transforming and the workers' capacity to adapt to such changes are not uniform across industries and countries.

The shortages of required skills put several constraints on growth and development by curtailing the prospects of increase in job creation and income. Coupled with mismatch between supply and demand of skills, it constrains productivity improvements. Such skill mismatches and skill shake ups have increased the need for regular skilling, and up-skilling throughout a person's career, because people with low skills are generally the first ones to lose jobs. So while technology advocates emphasize on its role in increasing productivity, income and thus employment; the pessimists point out towards its displacement effects on labour.

The association between technology, skills and productivity has long been discussed and empirically

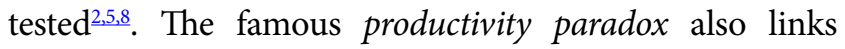
labour productivity and employment growth to the surge in technology (Information and Communication Technology, ICT). Global Competitiveness Report ${ }^{\frac{8}{}}$ points out the significance of skills (talent) in an economy to reap the benefits of the tech revolution and achieve higher productivity and growth in employment. It is argued 
that the new technology opens many new windows for investment and increase in productivity, a key to sustainable economic development but simultaneously requires new skills for growth of employment. The updated skills thus not only become a necessity but also help in employment and income. Since better skills are likely to lead to quick employment and higher income, for existing labour acquiring and updating skills would be the best insurance against job losses. However, the positive effects of new technology may be present only for skilled labour and where the forward and backward linkages between different firms and industries are strong and the effect may be negative for unskilled labour ${ }^{10}$. Thus, the overall macro effects may be uncertain and depend on many forward and backward linkages; besides growth in investment and total factor productivity.

India has not remained insulated from the impact of technology and has also contributed and benefited from its development. A number of firms have not only produced and exported IT enabled services but many of them have also absorbed both the domestic and the imported technology. The ICT producing and using industries thus have contributed in the growth of GDP and employment ${ }^{4}$. Using the firm level data for the Indian manufacturing and service industries, $\mathrm{Kumar}^{3}$ has also concluded that due to increase in ICT intensity the employment growth accelerated in the services sector firms but not in manufacturing firms.

The current study is aimed to clear some misgivings about the positive impact of ICT on employment by finding out how the pattern of growth in employment, value added and labour productivity differs between the ICT-producing, ICT-using and non-ICT industries of the Indian economy. Towards this aim, the paper first maps the Indian manufacturing and service industries, based on the ICT produced or used by them. The next section briefly discusses the methodology and the data set. In the subsequent Section 3, the paper summarizes the profile of the Indian industry and analyzes the long term pattern of value added, labour productivity and employment growth at aggregate level for the Indian economy and its manufacturing and service sector for the period 1999-2014. In Section 4, the paper explores the distribution of employment by education, a proxy for skills $s^{\mathrm{a}}$, in manufacturing and services sectors and its relationship with technology through its distribution in ICT (producing and using) and non-ICT industries. Finally, the paper concludes in Section 5.

\section{Data and Methodology}

The main data source for the current paper is the updated version of the India KLEMS ${ }^{\mathrm{b}}$ Database, December 2016, Reserve Bank of India (RBI) ${ }^{6}$ which provides time series data for for 27 Indian industries and the total economy. The data includes information on Gross Value Added (GVA) at constant prices (2004-05), Employment, Capital stock, etc. from 1980-81 to 2014-15. The current paper, however, restricts to 1999-2000 to 2014-15 because the pace of new technology took momentum in India around that time. The data set includes information on 27 industries (complete list in Appendix Table1) which includes agriculture, mining, 13 industries within manufacturing, electricity, construction, and 10 industries within services. The paper has used double deflated value added at constant prices $(2004-05=100)$ in Rs. Crores, total number of persons employed by Usual and Principal Status (UPSS) in thousands and total capital stock in Rs. Crores for the analysis ${ }^{c}$. Labour productivity is defined as the ratio of value added to employment. The trend is observed by the index of the value of the variables. The classification of industries into ICT-producing, ICT-using and non-ICT industries is mainly followed from ${ }^{1 \mathrm{~d}} \frac{3}{3}$.

The present study is restricted to to the non-agriculture sectors of the Indian economy and thus excludes agriculture and mining. The included 25 industries have been grouped into three- the ICT-producing industries (3); ICT-using industries (9) and non-ICT industries (13). The three ICT producing industries are namely Electrical and Optical Instrument that belongs to the manufacturing sector; Post and Telecommunication; and Business Services (includes Software and Hardware also) both from the services sector. All the variables have been computed for aggregate non-agriculture sector (25 industries), and for the manufacturing sector (13 industries) and the services sector (10).

\section{Trend in Value Added, Labour Productivity and Employment in Indian ICT-producing, ICT-using and Non-ICT Industries}

The section provides an overall view of the trend in Value Added (VA), Employment (Emp) and Labour Productivity (LP) of the Indian non-agriculture economy and its 

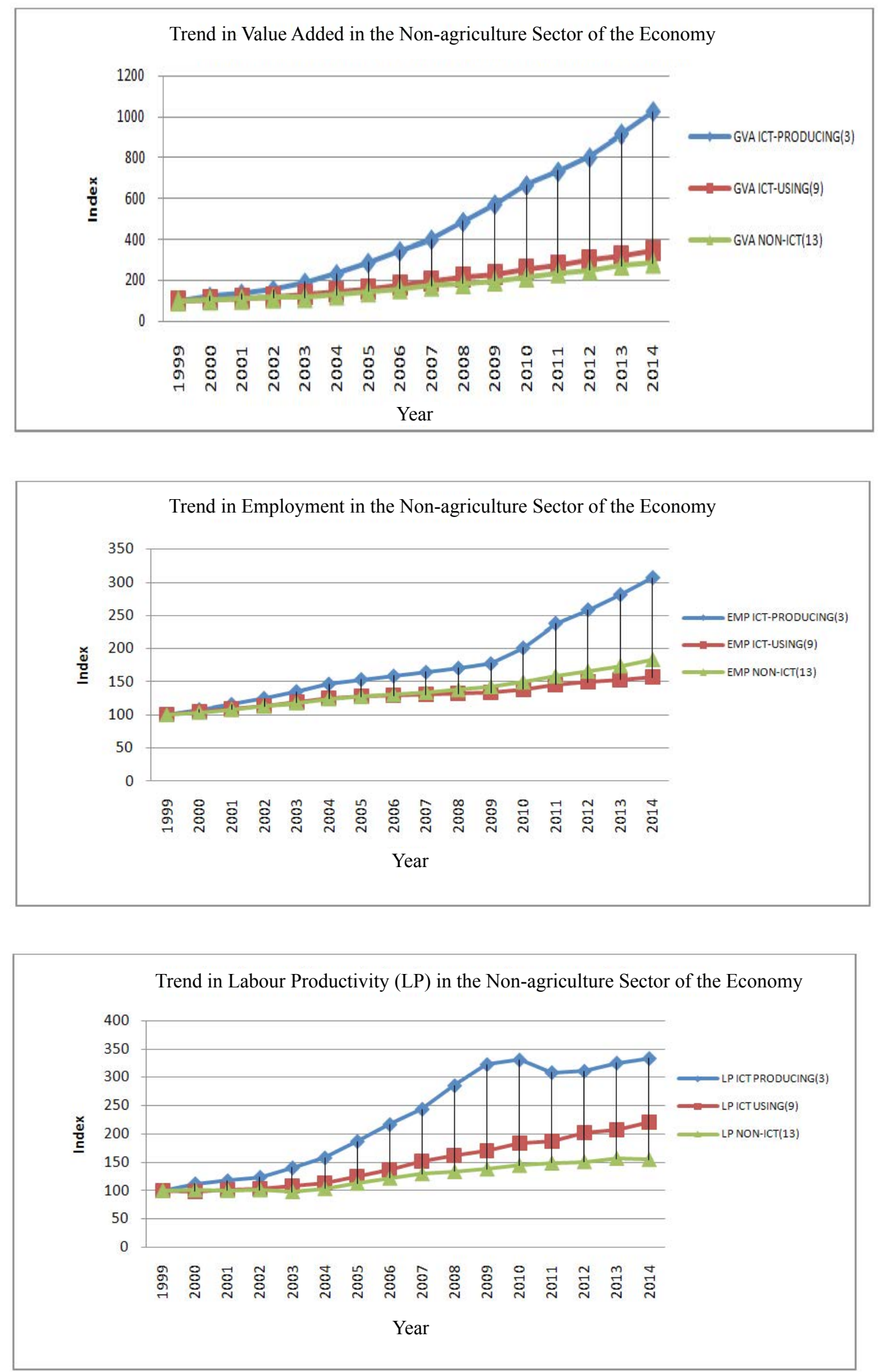

Source: Author's Computations

Figure 1. Aggregate Long Term Pattern in Value Added, Employment and Labour Productivity in Non-Agriculture Sectors of the Indian Economy by ICT-Producing, ICT-using and Non-ICT Industries 
manufacturing and services sectors. The manufacturing sector contributes 22 percent to VA and 21 percent to employment of the total non-agriculture sector of the Indian economy in 2014-15; while the shares were 17 percent and 28 percent respectively in 1999-00. We thus observe a relative increase in the share of value added and a fall in the share of employment in Indian manufacturing, a concern which has been repeatedly expressed in the current debate about the role which manufacturing will have to play in boosting employment in the economy. The services sector on the other hand witnessed a stagnant share in VA (around 66-67 percent) and also a falling share in employment (from 60 percent to 54 percent) during the same period. The two sectors together thus now have a lower share in employment and the share has gone up for the remaining other two industries- Electricity and Construction, which together contribute only 12.5 percent to VA but around 25 percent to employment of total non-agriculture sectors mainly because of the labour intensive nature of construction. However, the VA and employment pattern of manufacturing and services led to a faster rise in LP index for manufacturing (337 in 201415) than for services (209 in 2014-15).

In order to understand the role of technology in this trend, the analysis divides the industries into three groups: ICT-producing ${ }^{\mathrm{e}}$, ICT-using and non-ICT industries and traces the trend of VA, Emp, and LP (Figure 1). While the ICT-producing industries are not only small in number (only 3 out of 25), they contribute just 13.2 percent in VA and only 5.5 percent in Emp in 2014-15. For the same period, the corresponding share for ICT-using industries (9 industries) is 40 percent and 32.5 percent respectively. Thus, a substantial share of the VA and employment now is created by ICT-producing and ICT-using industries, major share being of ICT-using industries. It is also clear from Figure 1 that growth in all three- VA, Emp, and LP is highest in the group of ICT-producing industries as compared to the other two groups. While the ICT-using industry group has higher growth in VA and lower in Emp but the LP grew faster than the non-ICT industries. So, while the impact of technology may be ambiguous on growth of employment but that on LP is clearly growth enhancing. It is this substantial growth in VA in ICTusing and producing industries that their share in VA of aggregate non-agriculture sector has gone up by 10 percentage points from 43 percent to 53 percent.

To get a clear picture about the role, the analysis is further expanded to the manufacturing (13 industries) and the services sector (10 industries) separately (Figure 2 and Figure 3). Out of thirteen industries in the manufacturing sector, we find only one ICT-producing industry namely Electrical and Optical Equipment which contributes 8.7 percent of the total manufacturing VA and only 6 percent to its employment. The ICT-using industries, on the other hand contribute 23.4 percent and 21.4 percent to VA and EMP respectively. Thus, the two group of industries while contribute one-third of the value added, their share is only around one-fourth in employment. In panel 1 of Figure 2 , it is clearly discernible that growth in VA has been consistently higher in ICT-producing as well as in ICTusing manufacturing industries as compared to non-ICT manufacturing industries, though the pace is much higher for ICT-producing where the index rose nine times, than for ICT-using manufacturing industries where the index is just four times higher. However, the trend for employment (panel 2) is mixed, where the growth in employment in ICT-producing industry is initially lower but accelerated and outpaced the growth rates of other two groups only in 2009. Since 2009, the growth in employment in ICTusing industry has shown divergence and the index of employment has gone up to 279 for ICT-producing industry, and it is only 193 for ICT-using industries and 115 for non-ICT industries. Thus, one may infer that it is the ICT-producing industry which has generated faster employment growth. It is because of this pattern that the LP growth in ICT-using industry has been slower than the low employment generating non-ICT industries.

The services sector consisting of ten industries has a moderate share of 17 percent in the total service VA and 8 percent in the employment in 2014-15 from the two ICTproducing industries but the corresponding shares from ICT-using industries are quite substantial- around 50 percent in the total service industries. Figure 3 also clearly shows that ICT-producing and ICT-Using industries, which dominate the total service sector with six out of ten industries and contribute substantially to both total VA and total employment of the sector, experienced quite phenomenal growth rates. While the index of VA for ICTproducing industries (1050) is three times of ICT-using (334) and four times of non-ICT industries (248) in 201415 as compared to 1999-00; it is more than double for employment (317, 152 and 156 respectively). As a result we observe a sharp divergence in the trend of LP over the period and the ICT-using industries have consistently outperformed the ICT-using industries, which in turn outperformed the non-ICT industries. 

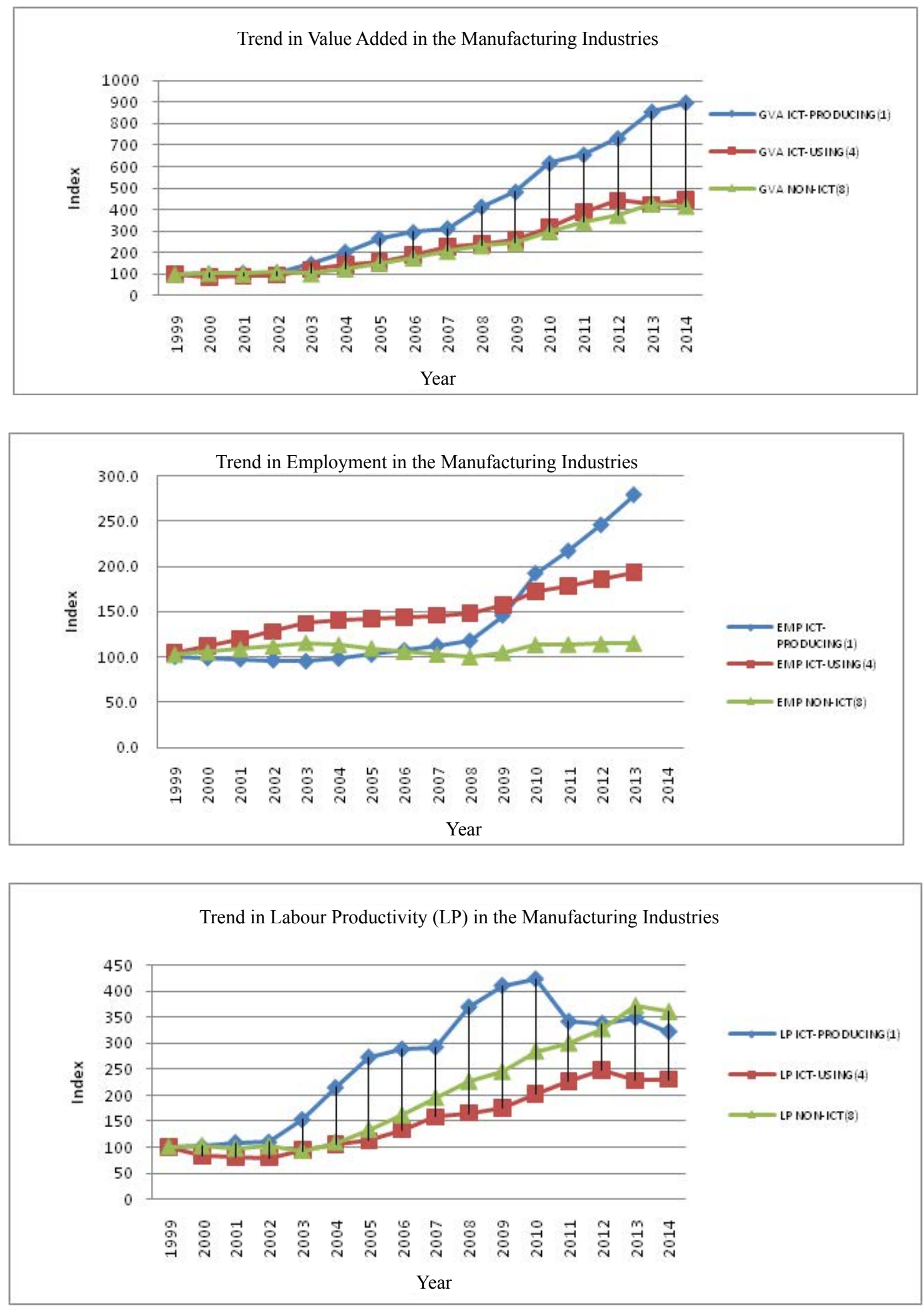

Source: Author's Computations

Figure 2. Long Term Pattern in Value Added, Employment and Labour Productivity in the Indian Manufacturing for ICT-Producing, ICT-using and Non-ICT Industries 

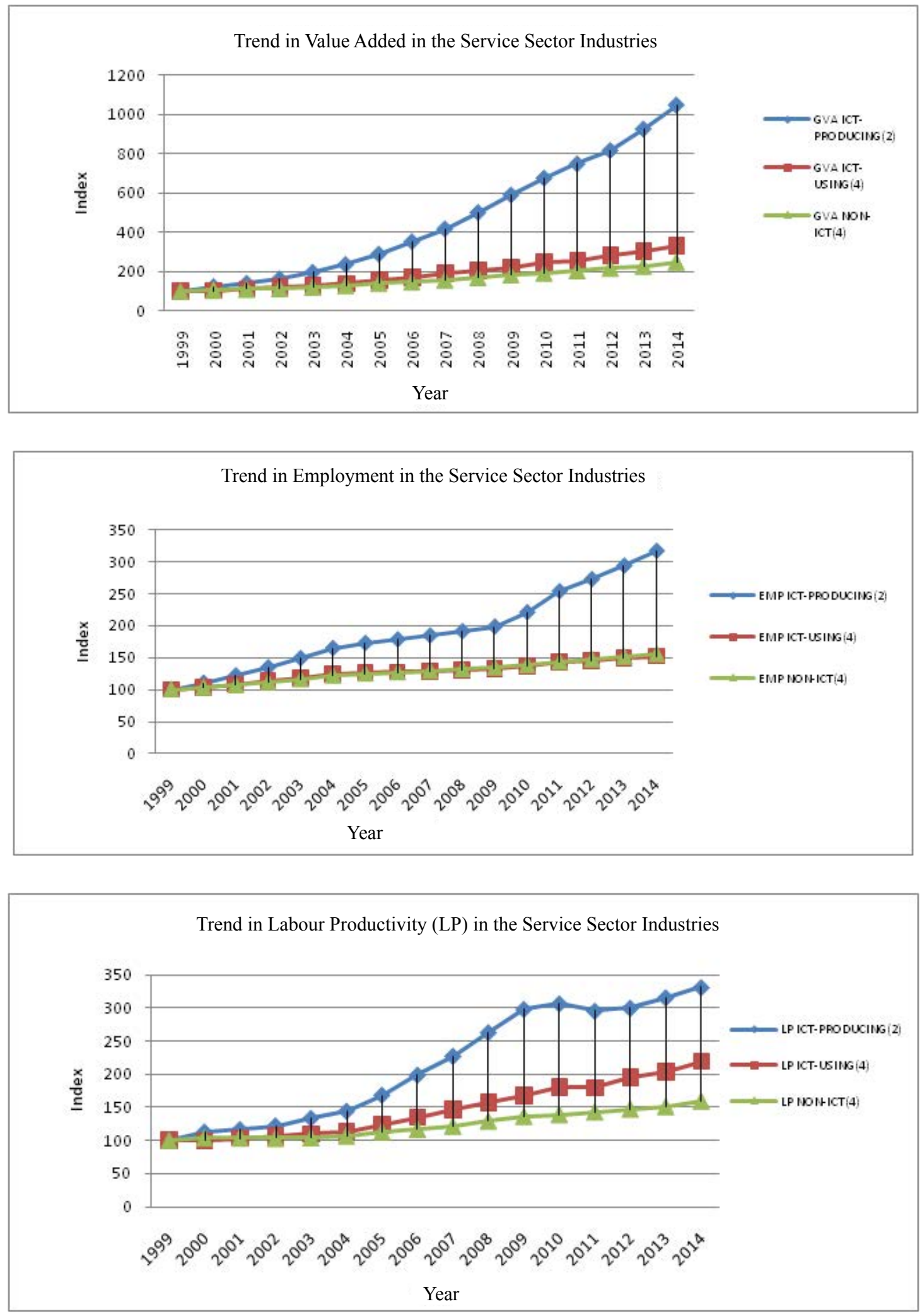

Source: Author's Computations

Figure 3. Long Term Pattern in Value Added, Employment and Labour Productivity for ICTproducing, ICT-using and Non-ICT Service Industries 


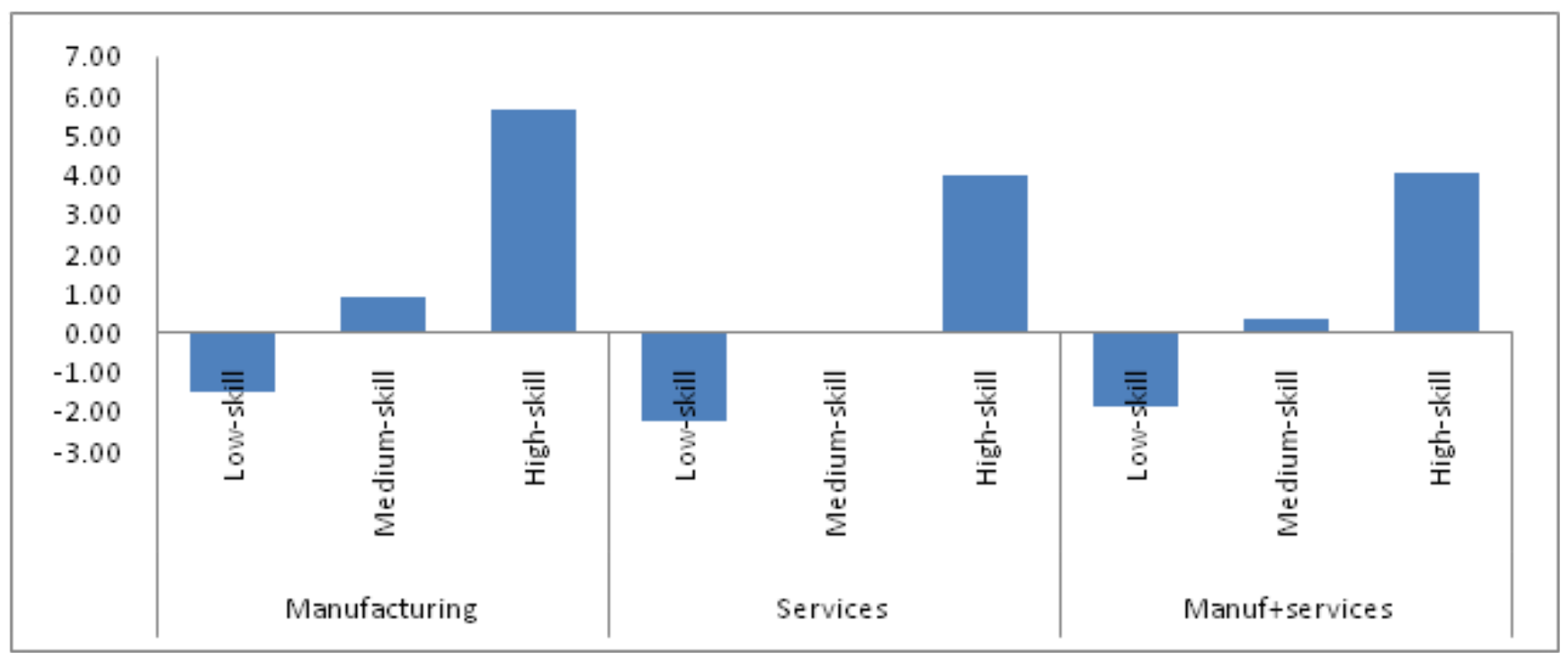

Source: Author's Computations

Figure 4. Average Annual Growth Rate of Employment by Skill in Manufacturing and Service Sector of the Indian Economy-1999-2000 to 2011-12

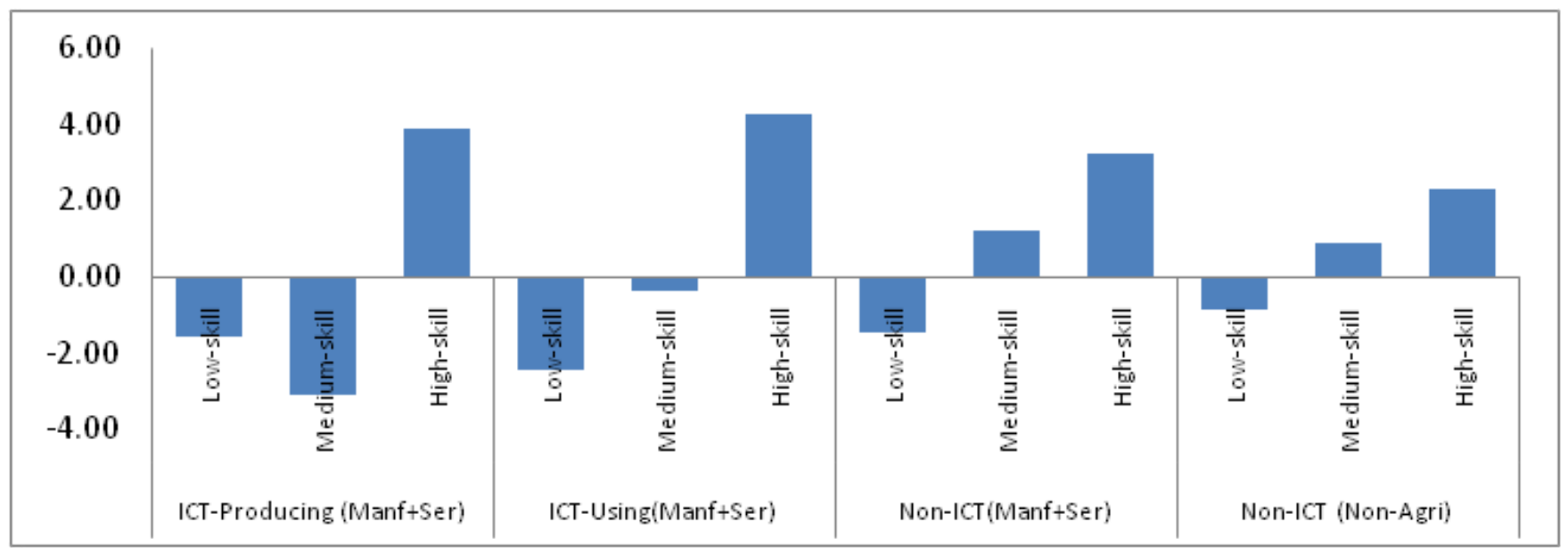

Source: Author's Computations

Figure 5. Average Annual Growth Rate of Employment by Skill in ICT-Producing, ICT-using and Non-ICT Industries of the Indian Economy- 1999-2000 to 2011-12

Thus, from Figures 1-3, one may conclude that over the period 1999-00 to 2014-15, the ICT-producing industries in the Indian non-agricultural sector, as well as in the manufacturing sector and the services sector have generally outperformed the ICT-using and non-ICT industries in terms of growth of VA, employment and labour productivity. It thus, is obvious from the experience at the industry level that new technology in the form of ICT has helped the Indian industry to accelerate its growth in VA, employment and LP. However, along with spread of technology there has also been an expansion of education and hence skills in the Indian economy.

\section{Growth in Employment by Education and Type of Industry}

The Indian economy has experienced an expansion in the general education level and the overall literacy level has increased despite a large illiterate/semi-literate population. The average literacy level of employed persons has gone up. The paper has grouped all education categories into three education levels namely (i) upto Primary (less than or equal to five years of education); (ii) between Primary and Hr. Secondary (from 5 years to 12 years of education); and (iii) above Hr. Secondary education 
level (more than 12 years of education). Since majority of Indian workers do not have much technical or any professional qualifications, the paper has taken education as a proxy for 'skills' and have defined corresponding skills as low-skill; medium-skill; and high-skill. One may argue that with the advent of new technology, it is essential that people must acquire higher skills to cope with the emerging demand for these skills.

The growth rates of employment by skills level for manufacturing sector, services sector and both sectors combined are presented in Figure 4 for the period 1999-00 to 2011-12 . In the combined manufacturing and service sectors, the proportion of high-skill employed persons has increased from 13 percent in 1999 to 21 percent in 2011 at a compound annual average growth rate of 4 percent. On the other hand the share of medium-skill employed persons remained stagnant at around 39-41 percent with a marginal growth rate of just 0.4 percent, but the share of low-skill employed persons declined by ten percentage points from 48 percent to 38 percent during the same period with the deceleration at the rate of 1.9 percent per annum. Thus, one may argue that the growth in employment is skewed towards higher skills. However, the change in the skill composition is not the same for both the manufacturing and the services sector. It is evident from Figure 4 that the average annual growth rate of high-skill employment in manufacturing is higher than that of the services sector. There has been a simultaneous growth in medium-skill employment in the manufacturing sector, which is missing in the services sector. However, both the sectors experienced a job contraction in the low-skill employment.

The general effect of new technology is therefore to increase demand (which generally may induce increased supply) of high-skill persons and the destroying effect is felt by the low-skill workers. The 'hollowing out' of middle level skills and growth in high skilled jobs by the 'disruptive' technology is also indicated by Global Competitiveness Report $\mathrm{t}^{9}$. However, in India the impact of the general spread of education is also visible in the composition of its workforce and its improved rank on 'education and training,' 'innovation' as well as on 'technological readiness' in 2017 Global Competitiveness Report, so there are now more employed persons with high skills. It is therefore interesting to look into the growth rate of employment in different types of industries based on ICT produced or used. A close examination of the growth in employment in Figure 5 clearly shows that over the period 1999-2011 while the employment of mediumskill and low-skill persons declined; the rate of growth in employment of high-skill persons is significantly higher in both ICT-producing and ICT-using industries as compared to non-ICT industries in total manufacturing and services. It is thus evident that technology has played a role in faster growth of employment of high-skill persons in the Indian manufacturing and service sector industries.

\section{Conclusion}

Since 2000, the new technology in the form of ICT has proliferated all over the World including India and has changed the nature and demands of Work. ICT has also been created and adopted by the Indian industry; especially the manufacturing and service sector industries. The other industries which include Agriculture; Mining; Electricity and Construction have a very limited exposure to ICT. The current study finds many important results on the relationship between new technology and employment. It is found that generally the ICT-producing industries, at aggregate and disaggregate level of manufacturing and service industries experienced a faster growth in value added, employment and labour productivity as compared to both ICT-using and non-ICT industries. The results confirm the role ICT may play in accelerating growth of labour productivity and employment. Moreover, like ICT-producing industries; the ICT-using industries also show evidence of higher gain in growth of value added and employment in the manufacturing sector. In the services sector, this evidence is confirmed for growth in value added but not for employment. The study also finds a link between technology and growth in the use of high-skill persons in manufacturing and the service sector industries. It is also observed that the growth in employment of high-skill persons is higher not only from medium and low-skill persons within both ICTproducing and ICT-.using industries, but also higher than the growth of high-skill persons in non-ICT industries.

Since technology in the form of ICT has helped in the accelerated growth in VA, Emp and LP in the Indian manufacturing as well as the service industries; it is evident that the Indian industry and its firms must pay more attention to investment in new technology and substantially increase their investment expenditure on Research and Development (R\&D) and firms should 
increase their readiness to adopt new technology to harness its potential economic and social benefits. It is all the more relevant and important in view of the dismal record of the Indian firms of investment in R\&D. The entire Indian industry in 2015 just spent the same amount as one Chinese company Huawei ( $\$ 6.5$ billion), and the total $\mathrm{R} \& \mathrm{D}$ expenditure by the Indian government was almost same as by one single US company- Microsoft ( $\$ 12$ billion in 2015). There were only 26 Indian companies among the top 2500 global R\&D spenders in $2015^{\frac{12}{2}}$. One of the most problematic factors for doing business in India as per the Global Competitiveness Report ${ }^{9}$ is 'inadequately educated workforce.' So unless India spends an adequate amount to spread and improve education, and the Indian industry starts realizing the gains of producing and of adopting new technology and spreads it from just less than half of the industries (12 ICT-producing and ICTusing industries out of 27 industry groups) to all the sectors; India's LP would remain low and GDP growth would not accelerate to the dream level of 10 percent per annum and the international competitiveness of its exports would continue to suffer.

\section{References}

1. Abdul AE, Das DK. Information and communication technology and economic growth in India. Telecommunications Policy. 2016; 40(5):412-31. https:// doi.org/10.1016/j.telpol.2015.08.006

2. Fields GS. Education and income distribution in developing countries: A review of the literature. Cornell University ILR School DigitalCommons@ILR; 1980.

3. Kumar P. ICT and employment in India: A sectoral level analysis. Research gate.net; 2017.

4. NASSCOM. Annual Report. New Delhi: NASSCOM; 2012.

5. Van Damme D. How closely is the distribution of skills related to countries' overall level of social inequality and economic prosperity? Paris: OECD. EDU NAEC Paper Series OECD; 2013.
6. Reserve Bank of India. Measuring productivity at the industry level - The India KLEMS database, RBI, Reports; 2016 Dec 9.

7. Reserve Bank of India. Time series data on productivity for 27 industries. RBI, Reports; 2016 Dec 9.

8. Schwab K. Global Competitiveness Report, 2016-17. World Economic Forum; 2016.

9. Schwab K. Global Competitiveness Report, 2017-18. World Economic Forum; 2017.

10. Ugur M, Mitra A. Technology adoption and employment in less developed countries: A mixed-method systematic review. World Development. 2017; 96(c):1-18. https://doi. org/10.1016/j.worlddev.2017.03.015

11. Cirillo V. Technology, employment and skills. Economics of Innovation and New Technology. 2016; 26(8). DOI: 10.1080/10438599.2017.1258765.

12. Making the most of the new industrial policy, Mint /opinion, September 25th 2017. p. 17.

\section{Notes:}

a Skill and education though are not exactly same, as many of the illiterate workers may have many traditional skills as carpenters, masons, weavers, etc. but for lack of credible and consistent data for skills over a period of time, the author has taken this very restrictive assumption.

${ }^{b}$ KLEMS stand for all the inputs used in producing an output- capital, labour, energy, materials and services.

${ }^{c}$ For construction of the variables, refer to Data Manual, India KLEMS, RBI, 2016.

d They made the distinction on the basis of the level of ICT intensity and have used a 26 industry classification.

${ }^{\mathrm{e}}$ It is to be made clear that while ICT-producing industries may have relatively higher capital intensity, but majority of the ICT-using industries are still highly labour intensive $(\mathrm{L} / \mathrm{K})$ and low capital intensive $(\mathrm{K} / \mathrm{L})$ industries. The study defines high, medium and low labour/capital intensity by ranking the industries into three groups in descending order of intensity (Appendix Table 1).

${ }^{\mathrm{f}}$ The period is truncated as the data is sourced from EUS, NSSO which is not available after the $68^{\text {th }}$ round of 2011-12. 
Appendix Table 1

\begin{tabular}{|c|c|c|c|c|c|c|}
\hline S.No. & KLEMS Industry Description & ISIC 3.1 & Type of Industry & $\begin{array}{l}\text { Classification } \\
\text { by ICT }\end{array}$ & $\begin{array}{l}\text { Labour } \\
\text { Intensity }\end{array}$ & $\begin{array}{l}\text { Capital } \\
\text { Intensity }\end{array}$ \\
\hline 1 & $\begin{array}{c}\text { Agriculture, Hunting, Forestry and } \\
\text { Fishing }\end{array}$ & A to $B$ & Others & non-ICT & HL & LK \\
\hline 2 & Mining and Quarrying & $\mathrm{C}$ & Others & non-ICT & HL & MK \\
\hline 3 & Food Products, Beverages and Tobacco & $15-16$ & Manufacturing & non-ICT & ML & MK \\
\hline 4 & $\begin{array}{c}\text { Textiles, Textile Products, Leather and } \\
\text { Footwear }\end{array}$ & $17-19$ & Manufacturing & non-ICT & ML & LK \\
\hline 5 & Wood and Products of Wood & 20 & Manufacturing & non-ICT & HL & LK \\
\hline 6 & $\begin{array}{c}\text { Pulp, Paper, Paper Products, Printing } \\
\text { and Publishing }\end{array}$ & $21-22$ & Manufacturing & ICT using & Low L & MK \\
\hline 7 & $\begin{array}{c}\text { Coke, Refined Petroleum Products and } \\
\text { Nuclear Fuel }\end{array}$ & 23 & Manufacturing & non-ICT & Low L & $\mathrm{HK}$ \\
\hline 8 & Chemicals and Chemical Products & 24 & Manufacturing & non-ICT & Low L & $\mathrm{HK}$ \\
\hline 9 & Rubber and Plastic Products & 25 & Manufacturing & non-ICT & Low L & $\mathrm{HK}$ \\
\hline 10 & Other Non-Metallic Mineral Products & 26 & Manufacturing & non-ICT & ML & MK \\
\hline 11 & $\begin{array}{l}\text { Basic Metals and Fabricated Metal } \\
\text { Products }\end{array}$ & $27-28$ & Manufacturing & non-ICT & Low L & $\mathrm{HK}$ \\
\hline 12 & Machinery, nec & 29 & Manufacturing & ICT using & ML & MK \\
\hline 13 & Electrical and Optical Equipment & $30-33$ & Manufacturing & ICT producing & ML & MK \\
\hline 14 & Transport Equipment & $34-35$ & Manufacturing & ICT using & Low L & $\mathrm{HK}$ \\
\hline 15 & Manufacturing, nec; recycling & $36-37$ & Manufacturing & ICT using & HL & LK \\
\hline 16 & Electricity, Gas and Water Supply & $40-41$ & Others & ICT using & Low L & $\mathrm{HK}$ \\
\hline 17 & Construction & 45 & Others & non-ICT & HL & LK \\
\hline 18 & Trade & $50-52$ & Services & ICT using & HL & LK \\
\hline 19 & Hotels and Restaurants & 55 & Services & non-ICT & $\mathrm{HL}$ & LK \\
\hline 20 & Transport and Storage & $60-63$ & Services & non-ICT & ML & MK \\
\hline 21 & Post and Telecommunication & 64 & Services & ICT producing & Low $\mathrm{L}$ & $\mathrm{HK}$ \\
\hline 22 & Financial Services & $65-67$ & Services & ICT using & HL & LK \\
\hline 23 & Business Services & $71-74$ & Services & ICT producing & ML & MK \\
\hline 24 & $\begin{array}{l}\text { Public Administration and Defense; } \\
\text { Compulsory Social Security }\end{array}$ & 75 & Services & non-ICT & Low L & $\mathrm{HK}$ \\
\hline 25 & Education & 80 & Services & ICT using & HL & LK \\
\hline 26 & Health and Social Work & 85 & Services & ICT using & $\mathrm{HL}$ & LK \\
\hline 27 & Other Services & $\begin{array}{c}7 \mathrm{O}+90+91+ \\
92+93+95+96\end{array}$ & Services & non-ICT & ML & MK \\
\hline
\end{tabular}

Notes:

1. The Industry classification is same as of KLEMS India ${ }^{6}$, RBI.

2. The ICT classification is based on ${ }^{1,3}$.

3. The labour intensity (HL,ML and Low L) and capital intensity (HK,MK, and LK) is computed by the author and the study defines high, medium and low labour/capital intensity by ranking the industries into three groups in descending order of intensity. 